\title{
JAMAICAN TAÍNO SETTLEMENT CONFIGURATION AT THE TIME OF CHRISTOPHER COLUMBUS
}

\author{
David V. Burley, Robyn P. Woodward, Shea Henry, and Ivor C. Conolley
}

\begin{abstract}
Stranded in Jamaica for a year in AD 1503, Christopher Columbus and crew became reliant on the Taíno village of Maima for provisions. Recent archaeological survey and excavations at this site document a sizeable hillside settlement established early in the White Marl period of Jamaican culture history with continued occupation up to Spanish contact. Beginning by 13th to 14th century $A D$, the people at Maima expanded their settlement capacity across the hillslope through construction of house terraces and platforms employing large volumes of limestone rock and gravel fill. Archaeological excavation on these features has exposed at least one circular, center-pole Taino house with a surprisingly limited floor space. A review of Jamaican archaeology suggests both hillside terracing and small house form is characteristic of Jamaican Taino village configuration more broadly. This pattern stands in contrast to other areas of Taíno settlement in the Caribbean, and to the small number of Spanish chronicles in which Taíno villages and houses are described.
\end{abstract}

Atrapados en Jamaica por alrededor de un año en 1503 d. C., Cristóbal Colón y su tripulación se vieron obligados a depender del aprovisionamiento de la aldea taína de Maima. Recientemente, en este sitio se han efectuado prospecciones y excavaciones arqueológicas que evidencian un importante asentamiento en las laderas, establecido tempranamente en el período White Marl de la historia cultural jamaiquina y con una ocupación continua hasta la etapa de contacto español. La población de Maima, establecida entre los siglos trece y catorce, expandió la capacidad de su asentamiento sobre las laderas a través de la construcción de terrazas habitacionales y plataformas empleando grandes cantidades de roca marga y relleno de grava. La excavación arqueológica en estos rasgos ha expuesto al menos una estructura circular que corresponde a una casa taíno de poste central con una superficie sorprendentemente limitada. Una revisión de la arqueología jamaiquina sugiere, en términos generales, que tanto el aterrazamiento de laderas como el tipo de casa pequeña son característicos de la configuración del pueblo taíno jamaiquino. Este patrón contrasta con otras zonas de asentamiento taíno en el Caribe y con las escasas crónicas españolas en las que se describen aldeas y casas taínas.

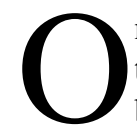
n May 5, 1494, during his second voyage to the New World, Christopher Columbus first encountered Jamaica and its indigenous peoples, naming the north coast harbor Santa Gloria (today St. Ann's Bay). Columbus returned to Santa Gloria on June 25, 1503, this time in desperation. His caravels La Capitana and Santiago were no longer seaworthy. Pulled together and beached, they became his bastion until he was rescued on June 29, 1504.
For that year the Spanish were reliant upon the Taíno for essential provisions. Central to this effort was Maima, a well-populated Taíno village a "quarter league" $(1.4 \mathrm{~km})$ distant from the ships (Morison 1963:367). When Diego Columbus, Governor of the Indies and son of Christopher, gave the command in 1509 to establish a Jamaican colony, Sevilla la Nueva, his knowledge of Maima and St. Ann's Bay were instrumental in its placement (Padron 2003).

David V. Burley — Department of Archaeology, Simon Fraser University, Burnaby, BC, Canada, V5A 1S6 (burley@sfu.ca, corresponding author)

Robyn P. Woodward $\square$ Department of Archaeology, Simon Fraser University, Burnaby, BC, Canada, V5A 1S6 (woodward1459@gmail.com)

Shea Henry Department of Archaeology, Simon Fraser University, Burnaby, BC, Canada, V5A 1S6 (shenry@ sfu.ca)

Ivor C. Conolley W Windsor, The Genesis Project, Sherwood Content P.O., Trelawny, Jamaica (ivorcconolley@ gmail.com)

Latin American Antiquity 28(3), 2017, pp. 337-352

Copyright (C) 2017 by the Society for American Archaeology

doi:10.1017/laq.2017.14 
The fate of the Jamaican Taíno encountered by Columbus and that of other Taíno peoples throughout the Greater Antilles is a tragic one: within a century these groups had been conquered and virtually disappeared (on Jamaica, see Wesler 2013:252-253). Despite the intensity of the Spanish-Taíno engagement over that period, only a handful of chronicles describe Taíno society in more than passing references. These chronicles, as Keegan (2013:70-72) notes, are not without problems either in their documentation or subsequent use. Of particular concern is their facilitation of a homogeneous ethnographic present for the Taíno of the Greater Antilles, one that denies potentially diverse histories, cultural and linguistic variation, and island-specific adaptations (Keegan 2007; Oliver 2009; Wilson 2007). ${ }^{1}$ A growing archaeological dataset and close inspection of the ethnohistorical sources suggest a complex reality (Curet 2003:22). The role of the archaeologist is to document the diversity of cultural expressions for the Taíno with emphasis, as Keegan (2013:81) states, on "the processes responsible for a multivalent Caribbean."

We contribute to this exercise for Jamaica through examination of Taíno settlement configuration as it existed in the village of Maima at the time of Spanish contact. Maima is strategically positioned on a hillside above the coastal plain, a topographic setting broadly characteristic of Taíno settlement patterns across the island. Archaeological research at Maima in 2014 and 2015 provides new insight into how this settlement type was accomplished through the use of artificial terraces and leveled platforms for Taíno house construction. Excavations on two of these terraces provide further documentation of the Jamaican Taíno house. In both settlement form and household features the Jamaican Taíno are distinctive within the scope of Caribbean archaeology.

\section{An Archaeological Context for Maima}

The historical record for Maima and the initial Taíno engagement with the Spanish is limited to a small number of references in the accounts of Columbus (Morison 1963), his son Ferdinand Columbus (Keen 1959), and Diego
Mendez, chief clerk of the fleet (Major 1961). Being the closest village to Columbus's ships in 1503, Maima was pivotal in the trade for provisions between the Spanish and the Taíno (Collard 1971:133; Padron 2003:8). Beyond this, Ferdinand Columbus describes Maima as the locale where his father's supporters defeated Captain Porras and his band of mutineers in 1504 (Keen 1959:280-281). It is unclear where or how Maima fits into the political landscape of the Taíno in Jamaica. The number of archaeological sites along the Jamaican north coast (AllsworthJones 2008:79) suggests a dense population in later prehistory, with village locations regulated by upland terrain features and freshwater drainage. In a review of the limited descriptions provided by the Spanish chronicles, Wesler (2013:253) suggests a multiplicity of caciques with at least one, Huareo, holding considerable authority. Nevertheless, the accounts allow no more than the assumption of a nested political hierarchy in which regional polities, cacicazgos, may have existed. That neither Columbus nor his son identified the name or authority of the Maima cacique could suggest a subordinate rank.

The archaeological site of Maima was first documented in the 1940s by the avocational archaeologist Charles Cotter, who found "a number of Arawak middens scattered over a large area" along "the bank of the dry riverbed known as Parson's Gulley” (Aarons 1984:28). TynsdaleBiscoe (1954) conducted additional excavations here in the early 1950s. In 1971 the government of Jamaica purchased the 300-acre Seville plantation, including Maima, to preserve and interpret the earliest history of the country within a heritage park. Leading up to the quincentennial celebration of Columbus's first voyage, Spain provided funding and archaeological expertise for research on the first Spanish colony of Sevilla la Nueva; director Lorenzo E. Lopez y Sebastian expanded this to incorporate test excavations at Maima in 1982 (Lopez 1986). The results of the Lopez project were never written up in more than cursory notation. The excavation units at Maima were not backfilled, however, and were easily located in more recent investigations.

In 2009 the Jamaican government submitted a nomination to UNESCO to have the "Seville Heritage Park" added to the World Heritage 


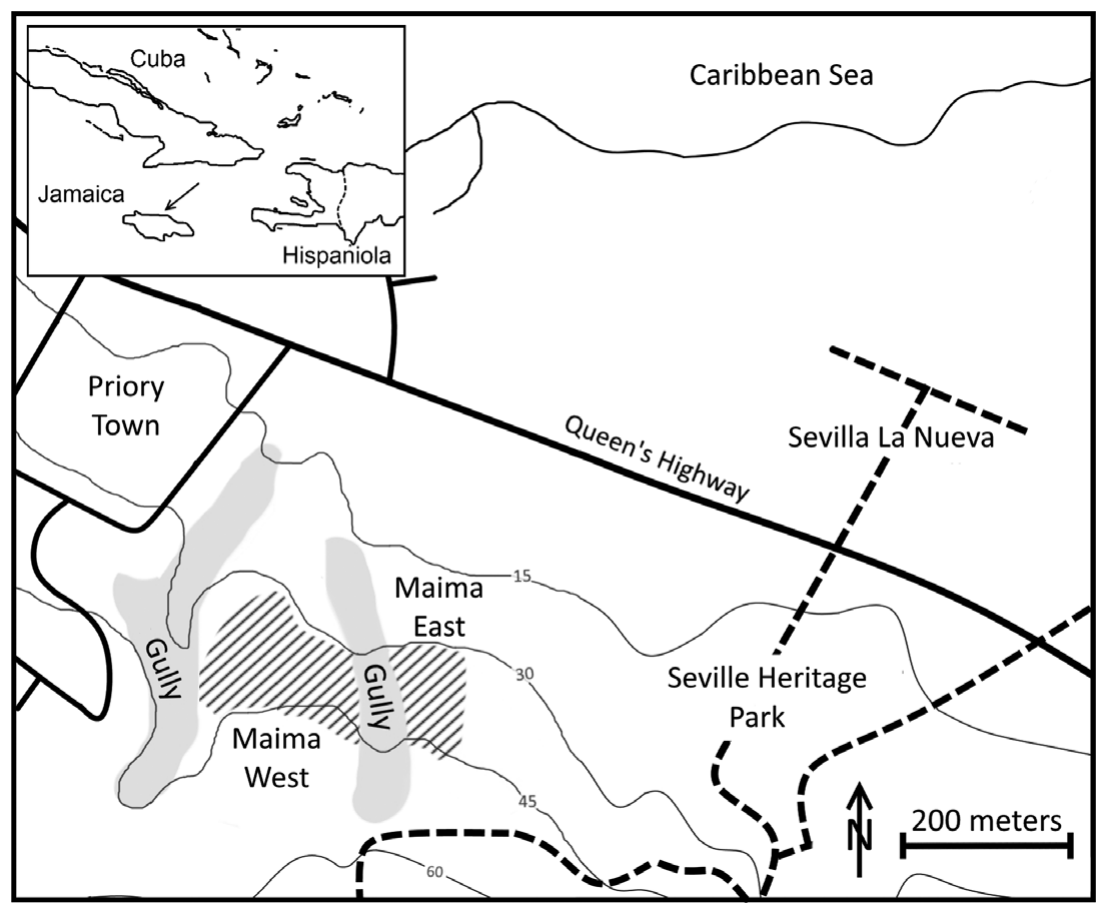

Figure 1. Jamaican Taíno Village of Maima, St. Ann's Bay, Jamaica.

List (it is presently on a Tentative List). Incorporating Maima, the Sevilla la Nueva colony, and the post-1655 British sugar plantation of New Seville, the nomination recognizes the "encounter, co-existence and merging of Taíno, Europeans and Africans at this site," giving "credence to the National Motto, Out of Many, One People" (UNESCO 2009). Our research provides support for the nomination but also planning and interpretive data for the Seville Heritage Park. Initial objectives thus focused on documentation of site size, complexity, internal configuration, and chronology and the potential impacts of contemporary land use. Initial survey was undertaken in 2014, with more concentrated study, including site mapping and controlled excavations, in the following year. The results are far more informative than we had expected.

\section{An Anthropogenic Hillscape of Terraces and Platforms}

Upland areas in the vicinity of St. Ann's Bay are formed by North Coast Belt bedded limestone of the Clarendon Block, Jamaican White Limestone Group (Robinson and Mitchell 1999). Contained within this are nodular or tabular layers of chert, a tool stone abundantly present in archaeological sites of the region. Initial archaeological survey on the hillslope identified as Maima quickly documented surface scatters of ceramics, lithics, and shellfish remains over an area of approximately 1.2-1.5 ha (Figure 1). The distribution of this material is dissected by a steep-sided gulley, leading us to reference the Maima site in east and west sections. Maima East occurs on farmland and bush adjacent to the Seville Estate proper; Maima West is densely populated as a squatters' settlement on untitled lands. In both segments, there is a north-to-south grade rising over a slope height of 10 to $15 \mathrm{~m}$ with notable terraces on the hillside. Controlled test excavations on select terraces in both east and west segments in 2014 illustrated that a number of these were constructed through intentional infilling, at least in part. This created leveled platform surfaces on which houses could be built. The 2014 project was able to identify four such features in Maima West; it is likely that others exist in inaccessible 
areas of the reclaimed village. The Maima East investigations also recorded several terraces and platforms. In 2015, these were cleared of vegetation and mapped in plan view (Figure 2) and with contours (Figure 3). As we are now able to document at Maima East, there is a minimum of 12 notable features distributed over several terrace levels. Three of these features had been excavated during the Lopez 1982 project.

Terraces and platforms are constructed of locally available limestone aggregate, marl, or clay occasionally intermixed with degraded ceramic sherds and other archaeological materials. Construction materials can be readily acquired from adjacent slopes and in the gully bottoms, where colluvial deposits are concentrated. The presence of cultural materials in the fills indicates the excavation and use of archaeological site matrices as additional constituents. Individual features are built outward from the upslope side to create a leveled surface. The thickness of the deposit consequently increases as it is added to on the down slope, with some of these fills being substantial. In the House 10 terrace, for example, a 2014 test excavation illustrates fill thickness of between 60 and $65 \mathrm{~cm}$ on the northern terrace edge (Figure 4). Another, from Maima West, documented a $45-50 \mathrm{~cm}$ deposit, and excavation of the most northern of the 1982 units into Platform 6 (Figure 2) would have removed $3.7 \mathrm{~m}^{3}$ of limestone aggregate or clay fill, given the unit size $(4.5 \times 2 \mathrm{~m})$ and stratigraphy.

In some cases where we have excavated through terrace fills, the original soil surface is encountered. This is shallow dark brown clay that typically overlies a variable subsoil of mixed clay with limestone aggregate or limestone bedrock (Figure 4). It is a rendzina soil closely matching descriptions of Killancholly clay as occurs elsewhere on the Jamaican north coast (Government of Jamaica 1964:10). Cultural materials occur within the subterrace soil, suggesting that terrace construction took place after initial site occupation. Subterrace diagnostic ceramics do not appear to be substantially different from those occurring on terrace surfaces (Figure 5); however, all correspond to a Meillacan ceramic variant defining the White Marl period (AD 950-1545) (Allsworth-Jones 2008:102; Wesler
2013:257). A 1-x-1-m excavation unit in House 8 (Figure 2) provides additional insight. The stratigraphy of this unit (Figure 6) incorporates a terrace fill of approximately $20 \mathrm{~cm}$ overlying stratified shell midden deposits up to $50 \mathrm{~cm}$ in thickness. The shell midden was positioned directly on top of limestone bedrock. Charcoalbased AMS radiocarbon dates from the lower and upper strata in the midden respectively are $938 \pm$ $20 \mathrm{BP}$ (Wk 43115, cal AD 1032-1151, 2 $\sigma$ ) and $627 \pm 20$ BP $($ Wk 43114, cal AD 1298-1390, $2 \sigma)$ (Table 1). The upper date provides a terminus post quem for House 8 terrace construction, if not for terrace construction at Maima more generally.

As we examined the terraces of Maima East, it was possible to predict locations of house structures based on our inference of slightly elevated features (Figure 2). Five of these had some type of excavation verifying initial impressions, with occupation materials atop an artificial platform. That other houses exist on these terraces seems highly probable. We also note that projected house locations occur on terrace edges above shallow basin-like depressions (Figure 2). Rainwater running downslope accumulates in these depressions, providing favorable areas for the potential planting of house gardens. The Taíno residents of Maima East may have enhanced these features by controlling the direction of drainage flow. In fact, the fill used to elevate terrace levels and construct house platforms may in part have been removed from these lower areas, serving a dual purpose of cut and fill in terrace construction.

\section{Early Sixteenth-Century Jamaican Taíno Houses at Maima East}

The excavation of architectural features in Jamaican archaeology has been virtually nonexistent. The discovery of terraces and platforms at Maima in 2014, therefore, was exciting for more than its engineering implications. If these were leveled surfaces upon which houses were constructed, they potentially represent a canvas onto which architectural features were imprinted. We have already noted the platform construction of House 10 and the substantial layer of fill on its northern perimeter. In 2015 


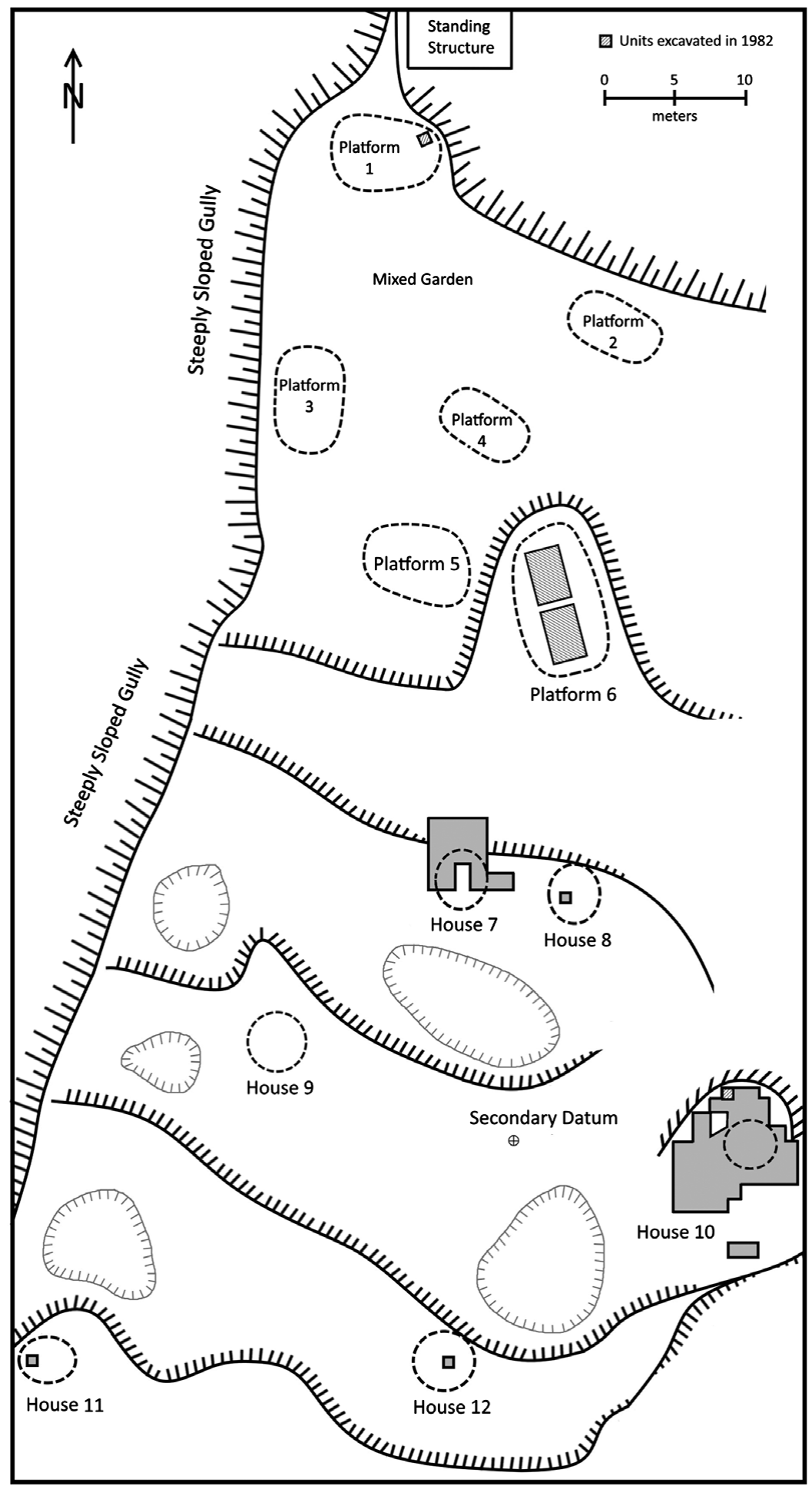

Figure 2. Plan view map of features and terrace breaks at Maima East. Platforms 1 and 6 and the House 10 terrace had open excavation units from the 1982 Spanish archaeological project. The depressions are 15 to $20 \mathrm{~cm}$ basin-like features. Darkened excavations were conducted in 2015. 

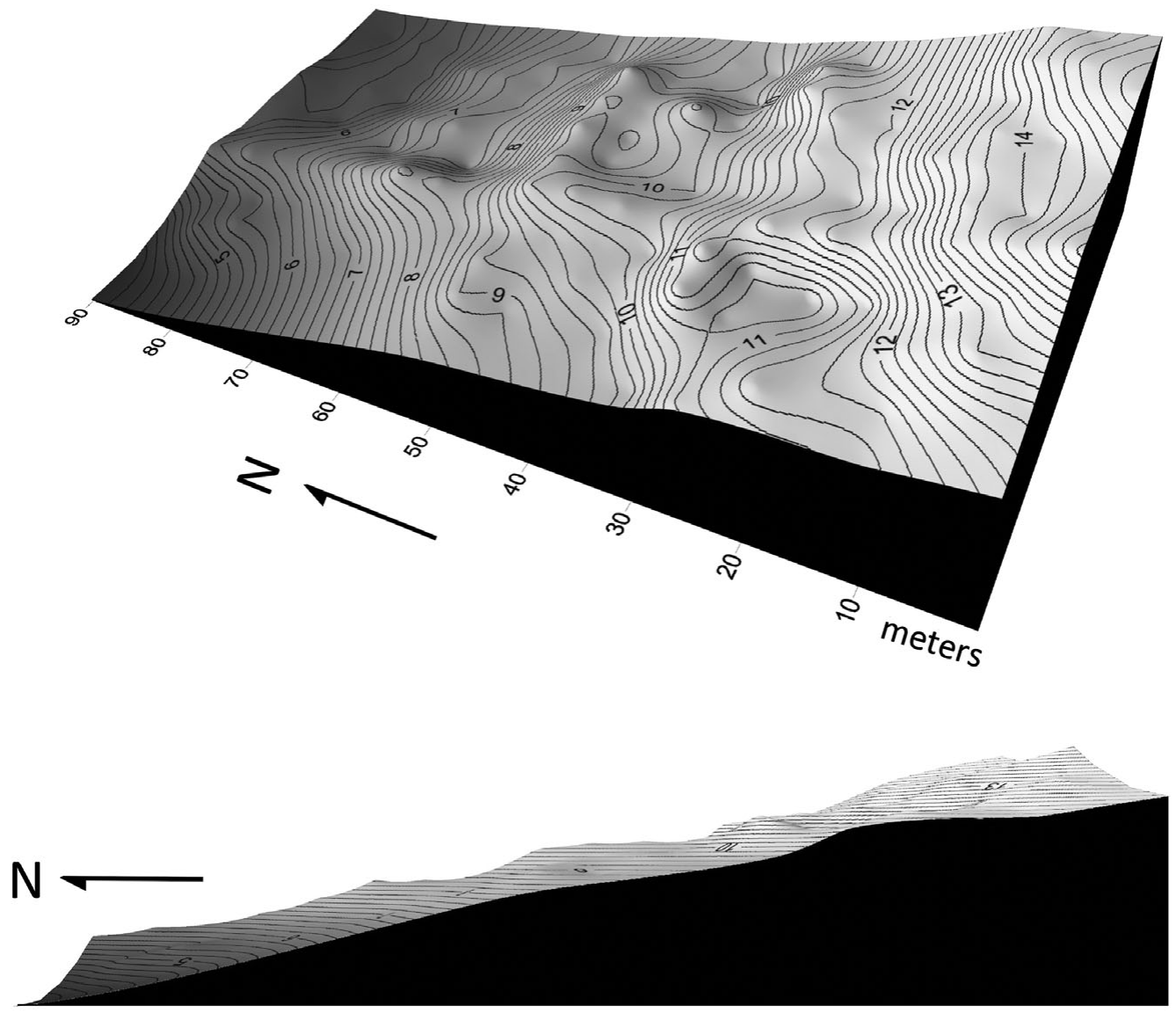

Figure 3. Contour elevation map $(20 \mathrm{~cm})$ for Maima East plotted with Surfer 3-D imaging software. Images are given in slope perspective and an oblique view illustrating terracing.
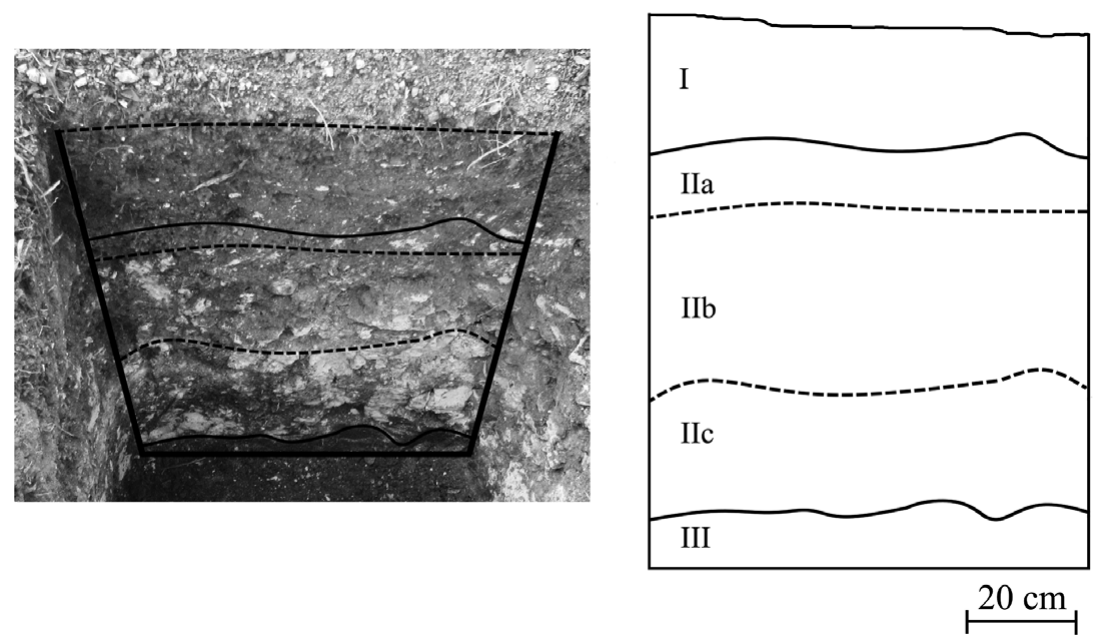

Figure 4. Stratigraphic profile from the northeast corner of the House 10 platform, Maima East, 2014. This section is an extension of a 1982 excavation unit that terminated at the Strata IIa-IIb transition. Stratum I is gray-brown loam. Stratum II includes sequential deposition of terrace fill layers, including mixed clay, limestone aggregate, and marl, with very limited cultural materials. Stratum III is the original clay soil on which the terrace was constructed. 


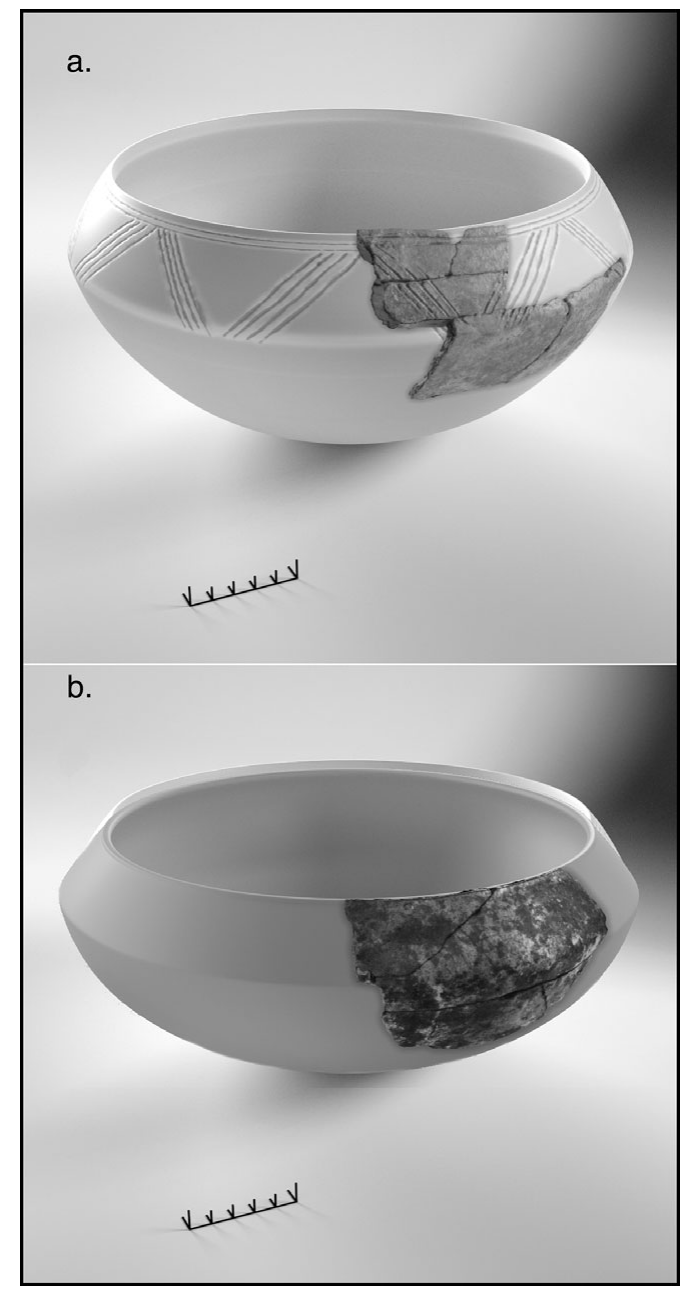

Figure 5. Typical White Marl period ceramic forms: (a) bowl recovered from occupation deposits above a limestone aggregate-filled terrace, 2014 test excavation at Maima West; (b) bowl recovered from below House 10 terrace fill (Stratum III), 2014 test excavation.

we removed surface loam from the terrace in search of the architectural imprint. House 7, first identified by an exposed bedrock feature on the perimeter of an intermediate terrace in the central part of Maima East, also was selected for excavation.

The House 10 excavation was successful in documenting a series of postholes defining a center-pole circular structure approximately $4 \mathrm{~m}$ in diameter (Figure 7). The perimeter postholes typically are $15 \mathrm{~cm}$ in diameter, running to a depth of 20 to $25 \mathrm{~cm}$. They have been excavated into the terrace surface and, in several cases, were supported by limestone rock packing. The central posthole is between 30 and $35 \mathrm{~cm}$ in diameter and extended from the surface to a depth of $45 \mathrm{~cm}$. This also was stabilized by packed limestone rock. Postholes were not found on the western side of the house, a circumstance that appears anomalous. Given trade wind directions from the east-southeast, this part of the house likely was the door location. It is possible, therefore, that its construction form was different from other walls. A substantial rock feature exposed on the outside perimeter of the house in this area may have provided a firm subfloor for the house entrance and the activities undertaken there. Rather than a leveled and even house floor surface, excavation of the platform exposed abundant limestone rock and an undulating occupation stratum. A naturally occurring, postoccupation drainage channel cut through the eastern side of the platform. We believe water flow across the platform removed finer marl sediments that previously composed the house floor and covered the platform surface. Thus, the dense concentrations of projecting rock fragments are washed-out and exposed fill constituents.

House 7 excavations were to examine a limestone bedrock exposure thought initially to be a retaining wall for a platform. Once excavated, the exposure was found to slope downward to the south, creating a pocket or basin-like depression that had been leveled with limestone aggregate mixed with clay and cultural materials. Eight postholes ranging in size from 9 to $17 \mathrm{~cm}$ in diameter were recorded but without definitive pattern. Notably, two sets of adjacent postholes had been cut into the bedrock (Figure 8), in a fashion similar to the "holster-formed postholes" documented by Samson (2010:142) at the El Cabo site in the Dominican Republic, but also present at several other sites in the Greater and Lesser Antilles (Samson et al. 2015:331). The nature of the platform and the materials recovered suggest a house floor occupation. If this were in fact the case, House 7 would be similar to House 10 in size based on the configuration of the bedrock basin. While built within a natural feature as opposed to an excavated depression, House 7 seems somewhat comparable to residential structures at site MC 6 in the Turks and Caicos (Keegan 2007:144). 
Table 1. AMS Radiocarbon Dates for Subterrace Cultural Occupations at Maima East, Jamaica.

\begin{tabular}{|c|c|c|c|c|c|}
\hline Sample & Context & Material & AMS Date & Cal $68.2 \%$ & Cal $95.4 \%$ \\
\hline Wk 43114 & House 8 Strata IVb & Unidentified Charcoal & $627 \pm 20 \mathrm{BP}$ & 1298-1390 AD & 1291-1395 AD \\
\hline Wk 43115 & House 8 Strata V & Unidentified Charcoal & $938 \pm 20 \mathrm{BP}$ & $1038-1151 \mathrm{AD}$ & $1032-1154$ AD \\
\hline
\end{tabular}

Note: The Waikato Radiocarbon Dating Laboratory, New Zealand, measured the dates. Calibrations were done with Calib 7.1 using IntCal 13 radiocarbon calibration curve (Reimer et al. 2013). These dates are based on the Libby half-life of $5568 \mathrm{yr}$ with correction for isotopic fractionation applied.

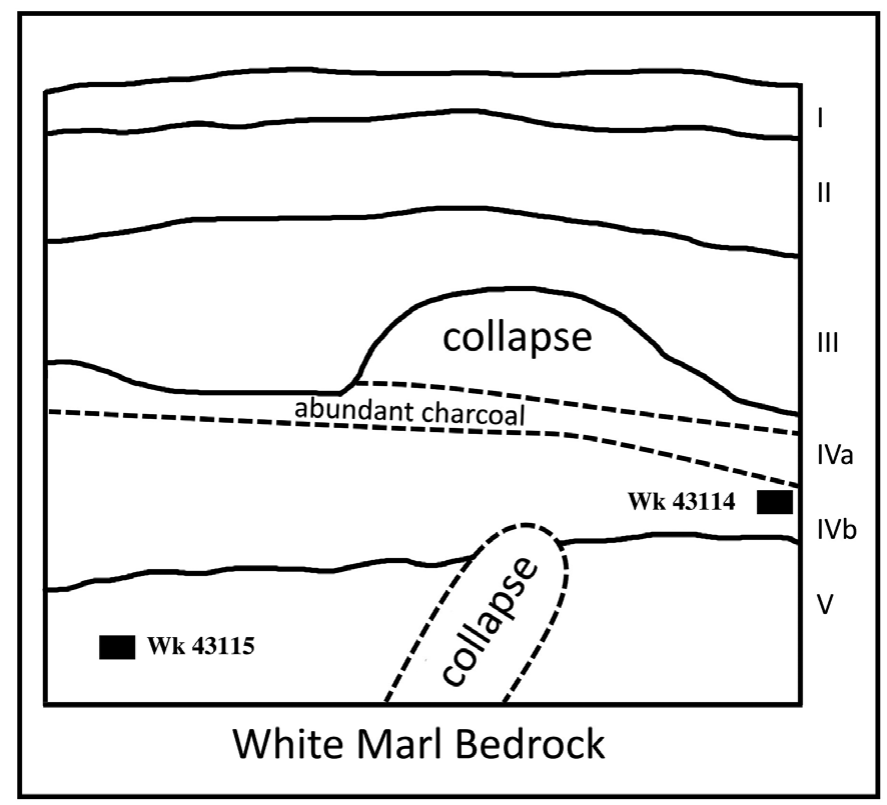

Figure 6. House 8 stratigraphic profile with AMS radiocarbon sample locations (see Table 1). Stratum I, surface loam; Stratum II, mottled occupation layer of blocky clay, shell, ceramics, and other cultural materials; Stratum III, light gray crushed and compact limestone aggregate and marl fill with limited cultural material (this stratum represents a terrace or house platform feature); Stratum IV, gray-brown mixed clay with organics, abundant cultural material, and shell; Stratum V (deposited directly onto limestone bedrock), very dark gray midden with packed shell, cultural materials, and limited clay.

Cultural materials recovered from the House 7 and 10 excavations are diverse in function and support our interpretation of residential occupation as opposed to storage structures. This includes petaloid adzes, a range of pestlelike handstones and manos, flat-surface cobbles for use with the handstones or as metates, net weights, abraders, flaked stone expedient tools, debitage, and branch coral sprigs. The ceramic assemblage for each is abundant; 7,215 sherds were excavated from House 7 and 11,568 pieces from House 10. A wide variety of vessel forms and sizes are present, including boatshaped forms with notched ends, and vessels with filleted rims, punctation on the rims, and coarsely applied geometric incision. Four anthropomorphic or zoomorphic adorno pieces may represent cemi (Taíno gods, spirits) imagery as applied to household ceramics. As we have noted, in its style and decorative application this assemblage conforms closely to ceramic types of the White Marl period as documented elsewhere in Jamaica.

Each of the house excavations recovered small assemblages of Spanish-derived artifacts, providing a post-Columbus end date for their individual occupations. From House 10 are six hand-forged nails, two fragments of glass, one with retouch, a piece of Spanish roof tile, a corroded piece of flat iron, and a sheep or goat 


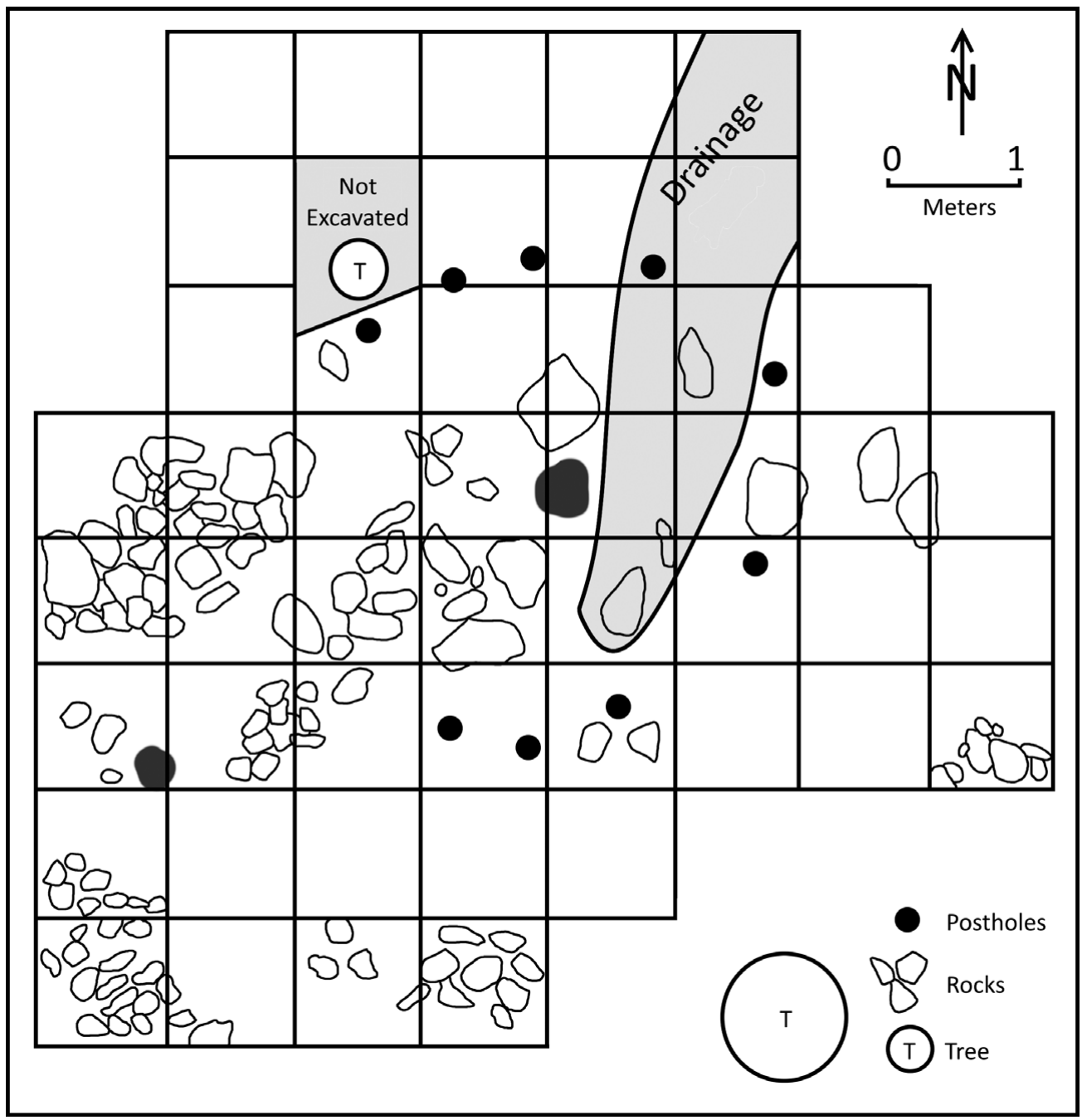

Figure 7. House 10 feature plan and posthole pattern. Exposed rocks are white limestone chunks incorporated into terrace fill. The drainage channel in upper right has cut through the terrace and is post-occupation in age.

metatarsal and phalange. Excavations in House 7 recovered a cow molar as well as a silver piece that may be the handle of a fork or spoon. A ceramic handle fragment from House 7 may have been part of a colonoware vessel, a Taíno replication of a European ceramic cup or handled bowl (Woodward 2006). The historic component is consistent with the AD 1509 to 1534 presence of Sevilla la Nueva; the Spanish colony was only 700 to $800 \mathrm{~m}$ east-northeast of Houses 7 and 10 (Padron 2003; Woodward 2009). Sevilla la Nueva was planned as an agricultural and ranching colony for local and regional markets. The allocation of Jamaican Taíno peoples to the colonists through encomienda, a forced system of labor, was immediate and central to the colony's role (Padron 2003:149-151). The impact of encomienda on Maima is unknown. The limited assemblage of historic materials in the households of Maima East, however, suggests the site was abandoned or its population forcibly removed shortly after the colony was established.

\section{Configuring the Jamaican Taíno Settlement Variant}

The Jamaican Taíno cultural variant, categorized by Rouse $(1948,1992)$ as "sub-Taíno" or 


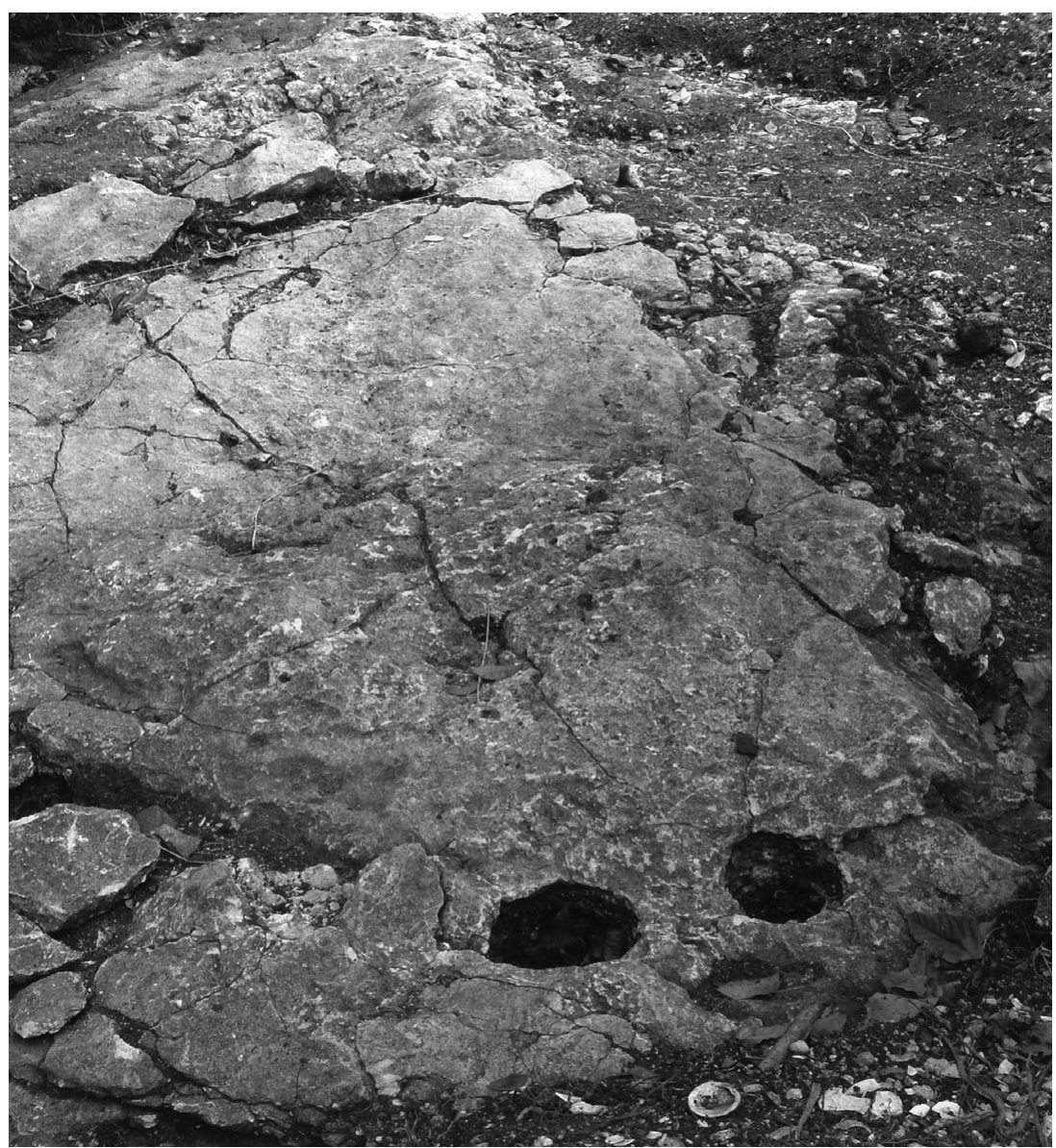

Figure 8. Dual posthole pattern excavated into limestone bedrock at House 7. The bedrock dips to the southeast (upper left corner of photo) to form a basin-like depression with limestone aggregate and abundant occupation materials. Left posthole is $17 \times 15 \mathrm{~cm}$, depth $22 \mathrm{~cm}$; right posthole is $10 \times 12 \mathrm{~cm}$, depth $17 \mathrm{~cm}$.

"western Taíno," has long been recognized as distinct from the "Classic Taíno" of Hispaniola, Puerto Rico, and eastern Cuba. This distinction served to emphasize the elevated sociopolitical complexity of the Classic Taíno chiefdoms as well as a corresponding overlay of cultural traits. A large part of that overlay is reproduced in settlement layout, in which chiefly position and social relations are clearly defined on the landscape through village patterning, by large chiefly houses strategically positioned on central plazas, and by the construction and use of stonelined ball courts (Alegría 1983; Deagan 2004; Keegan 2007). The settlement configuration we have described for Maima seems to be in stark contrast with this pattern. This, then, leads us to ask whether Maima is representative of Jamaican
Taíno settlement at the time of Christopher Columbus, and if it is, what the implications are for Jamaican Taíno society in comparison to Classic Taíno culture as documented elsewhere.

It may seem overly simplistic, but Atkinson (2006:6) fittingly describes the nature of Taíno settlement pattern in Jamaica by stating that "it is the general consensus among Jamaican archaeologists that Taíno sites have the best views [because] their sites are generally panoramic-located overlooking the landscape." Howard (1965:251) recognized this pattern early in the 1960s, observing that "most villages [occur] on hilltops overlooking the coastal plain and within reasonably easy access to the sea." In his documentation of site locations mapped by James Lee between 1959 and 1986, 
Allsworth-Jones (2008:CD-ROM) identifies 214 "middens" as having an association with the White Marl period. Only 17 of these occur at elevations below $15 \mathrm{~m}$ above sea level. His (2008:80-81) analysis of site geography additionally illustrates that a number of these sites are located well inland $(\bar{x}=4.57 \mathrm{~km})$ and many are at substantial elevations $(\bar{x}=160.85 \mathrm{~m})$. The location of Maima on sloped and terraced terrain above the coastal plain, therefore, is not atypical. Rather it is the norm for the White Marl period, and for the Jamaican Taíno settlement by extension.

The ubiquity of the hilltop settlement type throughout the White Marl period suggests its origins lay in an earlier ancestral pattern rather than a specific adaptation to the Jamaican landscape. White Marl and other late ceramic variants (Montego Bay, Port Morant) represent subseries of Meillacan Ostionoid ceramics as found elsewhere in Haiti, central Cuba, and the Dominican Republic (Rouse 1992:96-97). In form, decorative application, and other aspects of their production they are distinctively different from Redware ceramics (Ostionan Ostionoid subseries) of the preceding Little River period in Jamaica. This break is sufficiently abrupt to suggest a new wave of migration into Jamaica beginning around AD 950-1000 (Keegan and Atkinson 2006:26; Sinelli 2013:225). We believe that the people associated with this migration carried with them not only a Meillacan ceramic complex, but also a settlement pattern in which hillside or hilltop villages were central. In contrast, Little River period archaeological sites for the most part are positioned on the coast (Wesler 2013:256). The difference in settlement patterns between Meillacan and Ostionan complexes more generally has been noted by Rouse (1992:99) for other areas in the Greater Antilles. Upland village locales would seem to be an adaptation of ancestral Meillacan peoples that Sinelli (2013:224) positions ultimately in the Cibao Valley region of the northern Dominican Republic based on radiocarbon dates.

The uniqueness of the Maima village pattern relative to Meillacan sites elsewhere in the Greater Antilles lies in its use of constructed terraces and platforms. We cannot estimate how much fill may have been employed, but feel safe in describing the construction process as a serious investment of labor. We have noted that Meillacan ceramics in subterrace deposits are of the same White Marl types as those occurring on the terrace surface. There is no evidence to suggest that discontinuity in site occupation accounts for the appearance of terrace platforms. We conclude, therefore, that terrace fabrication at Maima is a late prehistoric Jamaican Taíno development. The upper $2 \sigma$ date range of cal AD 1291-1395 (Wk 43114; Table 1) for House 8 provides an approximate terminus post quem age for this activity. Why these features suddenly appeared at Maima is a subject of speculation. Their construction facilitates a greater ability to house an expanding population on the hillslope in keeping with a proliferation of Jamaican Taíno peoples in later prehistory (Rouse 1992:7). Their construction further enhances side-slope settlement in advantageously positioning the Taíno household for prevailing breezes as well as an elevated viewscape. That it alternatively may relate to unknown changes in other aspects of Taíno society cannot be ruled out.

During the 2014 survey and test excavation project at Maima, it was only near the end of the field program that we recognized the limestone aggregate, clay, and marl mix as artificial fills for terrace or platform construction. There was no precedent for the identification of terraces in the archaeological record of Jamaica, nor for that matter in most other areas of the Greater Antilles (Keegan 2007:145 provides an exception). Had it not been for the occasional degraded ceramic sherd or other items in these fills, the excavations might have been terminated on the assumption that we had reached an underlying basal stratum. We wonder, therefore, how many other archaeological projects at Jamaican Taíno sites had similar constructions that went unidentified. The 1982 test excavations at Maima East, for example, had cut through a terrace, presumably unrecognized (Platform 6 , Figure 2); an additional effort by the same crew to excavate a test in House 10 was also abandoned when the compact graveled surface was encountered (Figure 4). Scrutinizing past excavations in Jamaica in search of stratigraphic descriptions or drawings is not a simple task because most of this work remains unpublished 
or has been reported in only a cursory fashion. It is fortunate that Allsworth-Jones (2008:135184) has brought together the bits and pieces of data and individual excavation histories for a number of sites, with these projects spanning over a century of Jamaican archaeology.

The intentional deposition of marl layers on a Taíno site was first reported for the White Marl site, the type-site for the White Marl period. Early (1952-1954) excavations here by Tynsdal-Biscoe documented three cultural strata interleaved with "6 in" deposits of marl (as reported in Allsworth-Jones 2008:163). Reexcavation by Howard (1965:251) in the 1960s not only substantiated this claim but led him to conclude that "this marling is clearly artificial and not the result of wind action." That these layers could represent surface leveling for household floors or other activities was seemingly ruled out for lack of evidence (Silverberg 1972 as cited in Allsworth-Jones 2008:164). Howard suggested instead that the marl was used to "sweeten the site periodically" or represented a "pattern of ceremonial renewal." Neither was verified in subsequent studies.

The Allsworth-Jones account of archaeological excavation projects includes 28 sites identified as White Marl-Montego Bay period. Many of the descriptions are no more than a brief paragraph identifying earlier researchers who had undertaken the excavations; some include more in-depth discussion of the finds but say little about site stratigraphy. Nevertheless, a reading of these accounts makes it possible to isolate stratigraphic records for five White Marl sites and one Montego Bay site in which distinct cultural layers are separated by variously described marl or gravel strata (Table 2). Of particular note is the Fairfield site, a large hilltop village associated with the Montego Bay Meillacan ceramic variant (Allsworth-Jones 2008:149). Layer 4 (Trench 5) is described as a "marl layer, almost sterile" with radiocarbon dates on wood charcoal of cal AD 1310-1370 and cal AD 1270-1340 on cultural occupations above and below, respectively. (Conolley 2011:102, 112). These dates are all but identical to the terminus post quem suggested for the House 8 terrace at Maima East. Interpreting the intervening gravel-like layers as colluvium in their excavations at Green Castle and Newry,
Allsworth-Jones and Wesler (2012:30) underscore the complexity of site stratigraphy. They state that "site formation processes of Jamaican Taíno sites are a subject needing intensive further investigation in a geoarchaeological perspective."

New data also exist relating to residential construction and Jamaican Taíno settlement configuration. The House 10 posthole pattern documents a small center-post structure of no more than $4 \mathrm{~m}$ diameter with a floor area of approximately $12.57 \mathrm{~m}^{2}$ (Figure 3). If the infilled natural basin of House 7 is inferred to be a house floor occupation as well, it is of comparable size. Clearly these are not the large extended family household structures described for the Classic Taíno of Hispaniola and Puerto Rico (Deagan 2004:607; Samson 2010:57-60). They would not accommodate more than a small nuclear family, perhaps in the range of four to five individuals. With only one clearly defined structure, any attempt to generalize about the Jamaican Taíno house remains tentative if not speculative, especially given the stratified nature of Taíno sociopolitical organization. Yet the small amount of comparative information on household size from elsewhere in Jamaica is tantalizingly consistent. House 10, in fact, may provide a household template for the great majority of individuals who were resident at Maima at the time of Spanish contact.

Allsworth-Jones's assemblage of notes, reports, and difficult-to-acquire publications for individual site excavations is summarized in his text; supplementary maps, drawings, and other materials are incorporated in appendixes on a CD-ROM. A prominent site is BellevueManning's Hill, which was excavated in two areas between 1974 and 1977. As AllsworthJones (2008:156) relates, these excavations revealed "a circular arrangement of postholes convincingly interpreted as a house foundation." The plan-view map (Allsworth-Jones 2008:CDROM, Appendix 9) illustrates a circular to ovoid structure, between 3.8 and $4.3 \mathrm{~m}$ in diameter, that is defined by a series of 13 posthole clusters; most are adjacent pairs, but there are two larger postholes on the southwest and northeast perimeter. There is no central post or any indication of door location for the structure. Two aspects of this house are relevant to the present discussion. First, 
Table 2. Late Period Jamaican Taíno Village Sites.

\begin{tabular}{|c|c|c|c|}
\hline Site & Chronology & Stratum Description & Reference \\
\hline Bellevue-WR & White Marl & horizon of limestone rock & Allsworth-Jones 2008:146 \\
\hline Fairfield & Montego Bay & layer of sterile marl & $\begin{array}{l}\text { Allsworth-Jones 2008:149; Conolley } \\
\text { 2011:102 }\end{array}$ \\
\hline White Marl & White Marl & $\begin{array}{l}\text { pure soft marl marling is clearly } \\
\text { deliberate }\end{array}$ & $\begin{array}{l}\text { Allsworth-Jones 2008:162-165; } \\
\text { Howard 1965:251 }\end{array}$ \\
\hline Stewart Castle & White Marl & light colored marly material & Allsworth-Jones 2008:173 \\
\hline Rio Nuevo & White Marl & two layers of marl deposition & Allsworth-Jones 2008:176 \\
\hline Green Castle & White Marl & reddish gravelly large loose rubble & Allsworth-Jones 2008:180 \\
\hline Newry & White Marl & limestone rubble & Allworth-Jones and Wessler 2012:28 \\
\hline
\end{tabular}

Note: Includes sites for which stratigraphic descriptions indicate a marled layer intervening between cultural occupations. All sites are located on a hillslope or hilltop.

the postholes were visible "in a layer of hardened earth," suggesting an intentionally packed floor. Second, the floor area of 11.3-14.5 $\mathrm{m}^{2}$ comfortably overlaps with House 10 and House 7 at Maima East. It may be a coincidence, but the paired postholes of the Bellevue-Manning's Hill structure appear comparable to the posthole pairs excavated into the bedrock for House 7 at Maima East.

Allsworth-Jones (2008:161-168) provides a lengthy description of the excavation history for the White Marl type-site. Located in southeastern Jamaica, the site is a hilltop settlement $6.5 \mathrm{~km}$ from the ocean, with its original extent estimated to be as much as 33 acres (13.4 ha). Excavations by four different individuals were undertaken between 1952 and 1969 involving 11 excavation projects. In 1963, Howard (1965:252) excavated a block area in the central part of the site to search for residential features, but was not successful. Subsequent excavations by Clifford in 1969-1970, however, exposed "nine postholes indicating a circular structure of 14' [4.27 m]" (Allsworth-Jones 2008:167). The house entrance is described as being to the east, with a cooking area located to the west. This structure was similar to Bellevue-Manning's Hill in not having a central post; rather there was a centrally located "burned area" 12 in $(30.5 \mathrm{~cm})$ in diameter. A floor area of $14.3 \mathrm{~m}^{2}$ underscores once more the smallness of the Jamaican Taíno house, or at least one version of it in later prehistory.

A wide-ranging review of Caribbean household archaeology incorporating settlement layouts, house form data, and residential sizes can be found in Samson (2010). Tabulation of these data in a later paper (Samson et al. 2015:327) identifies 15 sites where excavations have exposed a total of 98 residential features. Most of these are post-built with round to oval floor plans varying in size from $10 \mathrm{~m}^{2}$ to $576 \mathrm{~m}^{2}$. Yet, excluding Bellevue-Manning's Hill, there are only six excavated houses with interior areas under $20 \mathrm{~m}^{2}$ (Samson et al. 2015:330), and these tend to be isolated occurrences on sites with much larger structures (e.g., Righter 2002:312). An intriguing exception to this occurs in south-central Cuba in the late prehistoric to contact period (Horizon III) hilltop site of Loma del Convento (Knight 2010:36-37). Here, a single center-post house was excavated with an estimated interior area of $13 \mathrm{~m}^{2}$. This house had been built on an uneven slope that was leveled to grade through the chipping-away of limestone bedrock, with postholes dug directly into bedrock.

Much debate and discussion has centered on the nature of Taíno (writ large) kinship and postmarital residence patterns (Keegan and Maclachlan 1989; Curet and Oliver 1998; Curet 2002; Keegan 2006). Within this debate it has been a given that settlement configuration and house form reproduce these relationships closely. They also represent, as Ensor (2013:85-87) suggests, material correlates for kinship without influence of the Spanish chronicles. We do not want to overplay the data from Maima East, yet we can say that the small size of Jamaican Taíno houses documented to date must be reflective of a nuclear rather than an extended family residential pattern. This, then, seems in contrast to the labor requirements of house terrace construction. In Puerto Rico, Curet and Oliver (1998:222- 
223) identify a dramatic transition from large communal households to smaller types characteristic of nuclear families between AD 900 and AD 1200. Correlated with changes in burial practices, the presence of ceremonial centers, and other cultural traits, they theorize an emergence and consolidation of power by chiefly elites, the demise of lineal descent groups, and increasing complexity in social and political spheres. The domestic unit of production may have been transferred to the individual household level (Keegan 2007:175), but caciques increasingly gained control over aspects of production and the organization of labor, land, and other resources (Curet and Oliver 1998:234). The transformation of the Maima East landscape into a hillslope of terraces may not have been conceived and undertaken at the individual family level. The cacique's increasing ability to mobilize labor for village expansion or improvements may well have been key to the Jamaican Taíno settlement configuration at the time of their first encounter with Christopher Columbus.

\section{Conclusion}

Spanish accounts of the Taíno peoples in the Greater Antilles pose dilemmas since these sources foster the impression of an undifferentiated ethnographic present. When these sources are applied indiscriminately in modern studies, it results in an "ethno-tyranny," to borrow a phrase from Maclachlan and Keegan (1990:1011), one that denies sociopolitical diversity, alternative historical trajectories, and linguistic variation. Archaeologists thus have a critical role to play: we are the frontline ethnographers for documentation of Taíno peoples as they lived their lives on various islands in the late fifteenth-century Caribbean. The present attempt to document and interpret Jamaican Taíno settlement configuration is therefore not framed against the usual backdrop of ethnohistorical sources. We believe the archaeological record of Maima provides a template for comparison or testing against the broader dataset derived from Jamaican archaeology. This has been done to the extent that the existing data allow.

In its settlement form Maima was a sizable hillslope village looking north across the coastal plain to the Caribbean Sea. We cannot be certain when it was first occupied, but a $2 \sigma$ calibrated radiocarbon date range of $\mathrm{AD}$ 1032-1154 (Table 1) suggests it was early in the White Marl period (AD 950-1545) of Jamaican antiquity. The proclivity for hillside or hilltop settlement, in fact, is characteristic of the White Marl period as a whole, suggesting it is part of an ancestral Meillacan settlement pattern brought to Jamaica in the tenth century AD Perhaps in response to increasing Taíno population growth, by the thirteenth to fourteenth centuries AD the people at Maima had expanded their settlement capacity through construction of house terraces or platforms. Some of these appear to have been major undertakings requiring the transport of volumes of broken limestone, marl, and other fills. The few archaeological reports on Jamaica that describe stratigraphy in detail suggest this adaptation is a widespread phenomenon. Recorded details of the Jamaican Taíno house form include circular structures with or without central poles, illustrating a degree of diversity in their construction. A surprisingly limited floor space is a constant, however, a characteristic that contrasts with the extensive construction efforts devoted to the terrace itself.

The work at Maima is ultimately but a small contribution to the documentation of Jamaican Taíno society at first Spanish contact. Even so, much more detail about the site will be required before we can generalize about it in a categorical way. It does provide a starting point for future examination of Jamaican Taíno peoples within the Greater Antilles region. We hope that further studies will expand upon this base, clarify the pattern, and provide greater insight than current data permit.

Acknowledgments. Archaeological fieldwork at Maima was carried out under permit from the Jamaican National Historic Trust. We acknowledge and thank Trust staff, particularly Dorrick Gray and Michelle Topping, for their support. Staff at the Seville Heritage Park were also accommodating in providing a logistical base for the project. Our Jamaican field crews in 2014 and 2015 were exceptional and are deserving of our gratitude. Fieldwork was supported in part by a Social Sciences and Humanities Research Council of Canada small projects grant in 2014 and SFU Faculty of Environment Chairs research grants to Burley in 2014 and 2015. We thank Vienna ChiChi Lam for skillfully drafting the maps and 
stratigraphic drawings and Edgar Abreu-Lanza for preparing the 3-D ceramic images in Figure 5.

Data Availability Statement. Excavated archaeological collections are retained by the Jamaican National Historic Trust and maintained in storage at the Great House, Seville Heritage Park, St. Ann's Bay, Jamaica. Original excavation documents are currently retained by D. Burley in the Department of Archaeology, Simon Fraser University.

\section{References Cited}

Aarons, Anthony

1984 Sevilla la Nueva: Microcosm of Spain in Jamaica, Part 2. Jamaica Journal 17(1):28-37.

Alegría, Ricardo E.

1983 Ball Courts and Ceremonial Plazas in the West Indies. Yale University Publications in Anthropology No. 79, Yale University, New Haven.

Allsworth-Jones, Philip

2008 Pre-Columbian Jamaica. University of Alabama Press, Tuscaloosa. With CD-ROM.

Allsworth-Jones, Philip, and Kit W. Wesler

2012 The Taino Settlement at Guayguata, Excavations in St Mary Parish, Jamaica. BAR International Series 2407, Archaeopress, Oxford.

Atkinson, Lesley-Gail

2006 Introduction. In The Earliest Inhabitants: The Dynamics of the Jamaican Taíno, edited by LesleyGail Atkinson, pp.1-10. University of the West Indies Press, Mona, Jamaica.

Collard, Andrée

1971 Bartolomé de las Casas, History of the Indies. Harper and Row, New York.

Conolley, Ivor C.

2011 Montego Bay Pottery and Culture in Western Jamaica: Significance and Implications for Jamaican Taíno Prehistory. Unpublished Ph.D. dissertation, Department of History and Archaeology, University of the West Indies, Mona, Jamaica.

Curet, L. Antonio

2002 The Chief is Dead, Long Live... Who? Descent and Succession in the Protohistoric Chiefdoms of the Greater Antilles. Ethnohistory 49:259-280.

2003 Issues on the Diversity and Emergence of Middle-Range Societies of the Ancient Caribbean: A Critique. Journal of Archaeological Research 11: $1-42$.

Curet, L. Antonio, and Jose R. Oliver

1998 Mortuary Practices, Social Development, and Ideology in Precolumbian Puerto Rico. Latin American Antiquity 9:217-239.

Deagan, Kathleen

2004 Reconsidering Taíno Social Dynamics after Spanish Conquest: Gender and Class in Culture Contact Studies. American Antiquity 69:597-626.

Ensor, Bradley E.

2013 Kinship and Social Organization in the Pre-Hispanic Caribbean. In The Oxford Handbook of Caribbean Archaeology, edited by William F. Keegan, Corinne L. Hofman, and Reniel Rodriguez Ramos, pp. 84-96. University of Oxford Press, Oxford.
Government of Jamaica

1964 Major Soil Types of Jamaica, Revised July 1964. Electronic document, http://www.moa.gov. $\mathrm{jm} /$ International $\% 20$ Year\% 20of\%20Soils/MAJOR\% 20SOIL\%20TYPES.pdf. Accessed June 19, 2017.

Howard, Robert R.

1965 New Perspectives on Jamaican Archaeology. American Antiquity 31(2):250-255.

Keegan, William F.

2006 All in the Family: Descent and Succession in the Protohistoric Chiefdoms of the Greater Antilles-A Comment on Curet. Ethnohistory 53:383-392.

2007 Taino Indian Myth and Practice: The Arrival of the Stranger King. University Press of Florida, Gainesville.

2013 The "Classic" Taíno. In The Oxford Handbook of Caribbean Archaeology, edited by William F. Keegan, Corinne L. Hofman, and Reniel Rodriguez Ramos, pp. 71-83. University of Oxford Press, Oxford.

Keegan, William F., and Lesley-Gail Atkinson

2006 The Development of Jamaica Prehistory. In The Earliest Inhabitants: The Dynamics of the Jamaican Taíno, edited by Lesley-Gail Atkinson, pp.13-29. University of the West Indies Press, Mona, Jamaica.

Keegan, William F., and Morgan D. Maclachlan

1989 The Evolution of Avunculocal Chiefdoms: A Reconstruction of Taíno Kinship and Politics. American Anthropologist 91:613-630.

Keen, Benjamin

1959 The Life of the Admiral Christopher Columbus by his Son Ferdinand. Rutgers University Press, New Brunswick, New Jersey.

Knight, Vernon J.

2010 La Loma Del Convento: Its Centrality to Current Issues in Cuban Archaeology. In Beyond the Blockade: New Currents in Cuban Archaeology, edited by Susan Kepecs, Anthony A. Curet, and Gabrino LaRosa Corzo, pp. 26-46. University of Alabama Press, Tuscaloosa.

Lopez y Sebastian, Lorenzo E.

1986 El Proyecto Sevilla la Nueva, Jamaica: Primera Fase. Revista Española de Antropología Americana. XVI:295-302.

Maclachlan, Morgan D., and William F. Keegan

1990 Archeology and the Ethno-Tyrannies. American Anthropologist 92:111-1013.

Major, R. H. (editor)

1961 Christopher Columbus: Four Voyages to the New World; Letters and Selected Documents. Corinth Books, New York.

Morison, Samuel Elliot

1963 Journals and Other Documents on the Life and Voyages of Christopher Columbus. Heritage Press, New York.

Oliver, Jose R.

2009 Caciques and Cemi Idols: The Web Spun by Taíno Rulers between Hispaniola and Puerto Rico. University of Alabama Press, Tuscaloosa.

Padron, Francisco Morales

2003 Spanish Jamaica. Translated by Patrick E. Bryan. Ian Randle Publishers, Kingston, Jamaica.

Reimer, Paula J., Edouard Bard, Alex Bayliss, J. Warren Beck, Paul G.Blackwell, Christopher Bronk Ramsey, and Caitlin E. Buck et al.

2013 IntCal13 and MARINE13 Radiocarbon Age Calibration Curves 0-50,000 years cal BP. Radiocarbon 55(4):1869-1887. 
Righter, Elizabeth

2002 Posthole Patterns: Structures, Chronology and Spatial Distributions of the Tutu Site. In The Tutu Archaeological Village Site: A Multidisciplinary Case Study in Human Adaptation, edited by Elizabeth Righter, pp. 284-341. Routledge, London.

Robinson, Edward, and Simon F. Mitchell

1999 Upper Cretacious to Oligocene Stratigraphy in Jamaica. In Middle Eocene to Oligocene Stratigraphy and Palaeogeography in Jamaica: A Window on the Nicaragua Rise, edited by S. F. Mitchell, pp. 1-24. UWI Mona Contributions to Geology 4. University of the West Indies, Mona, Jamaica.

Rouse, Irving B.

1948 The West Indies. In Handbook of South American Indians, Vol 4, The Circum-Caribbean Tribes, edited by Julian Steward, pp. 495-564. Bulletin of American Ethnology 143, Cooper Publishers, New York.

1992 The Taino: Rise and Decline of the People Who Greeted Columbus. Yale University Press, New Haven.

Samson, Alice V. M.

2010 Renewing the House: Trajectories of Social Life in the Yucayeque (Community) of El Cabo, Higueey, Dominican Republic, AD 800 to 1504. Sidestone Press, Leiden.

Samson, Alice V., C. A. Crawford, M. L. P. Hoogland, and Corine L. Hofman

2015 Resilience in Pre-Columbian Caribbean HouseBuilding: Dialogue between Archaeology and Humanitarian Shelter. Human Ecology 43:323337.

Sinelli, Peter T.

2013 Meillacoid and the Origins of Classic Taíno Society. In The Oxford Handbook of Caribbean Archaeology, edited by William F. Keegan, Corinne L. Hofman, and Reniel Rodriguez Ramos, pp. 221-231. University of Oxford Press, Oxford.

Tynsdale-Biscoe, J. S.

1954 Arawak Specimens from Some Middens of Jamaica. Jamaican Historical Society Bulletin 1(10): 123-126.
UNESCO (United Nations Educational, Scientific and Cultural Organization)

2009 World Heritage Center, Tentative Lists, Seville Heritage Park. Electronic document, whc.unesco.org/ en/tentativelists/5431. Accessed June 19, 2017.

Wesler, Kit

2013 Jamaica. In The Oxford Handbook of Caribbean Archaeology, edited by William F. Keegan, Corinne L. Hofman, and Reniel Rodriguez Ramos, pp. 250-263. University of Oxford Press, Oxford.

Wilson, Samuel M.

2007 The Archaeology of the Caribbean. Cambridge University Press, Cambridge.

Woodward, Robyn P.

2006 Taíno Ceramics from Post Contact Jamaica. In The Earliest Inhabitants: The Dynamics of the Jamaican Taíno, edited by Gail-Lesley Atkinson, pp. 161-176, University of the West Indies Press, Mona, Jamaica.

2009 Sevilla la Nueva: A Review of 72 Years of Archaeological Investigations. In Xaymaca: Life in Spanish Jamaica; 1494-1655, compiled by Institute of Jamaica, Jamaica National Heritage Trust and Ministry of Culture, Spain, pp. 32-44, Institute of Jamaica, Kingston.

\section{Note}

1. A reviewer for this paper has observed that despite our agreement with epistemological concerns over the use of "Taíno" in reference to indigenous peoples of the Greater Antilles, we continue to use the concept in much the same way that it has been used in the past. Within the paper we do use "Taíno" as a gloss in reference to indigenous peoples in the Greater Antilles who share linguistic and ancestral relationships, as do most Caribbean archaeologists. We expect, however, that there will be regional variation in culture, adaptation, and other traits. Indeed, the objective of the paper is to document a part of this variation as it relates specifically to the Jamaican Taíno.

Submitted July 11, 2016; Revised October 14, 2016; Accepted March 30, 2017 